\title{
As linhas tortas da Providência no romance de Manzoni
}

\author{
PEDRO GARCEZ GHIRARDI
}

$\mathrm{F}$

OI HÁ VINTE anos, em 1986. Um professor da USP, então ainda jovem, entregava ao editor a tradução de uma longa entrevista de Alberto Moravia.

Eram páginas em que o escritor tratava de vários assuntos, da política ao cinema. Tratava, principalmente, de literatura e do ofício de escrever romances. Nesse ponto a conversa se voltava para Manzoni e para I promessi sposi, ou, como se costuma traduzir, Os noivos. Ao falar do criador do romance italiano, Moravia começava por elogios, para terminar com restrições. Vale a pena ler esse trecho. A tradução é a do professor de 1986 que, vinte anos menos jovem, é quem agora aqui escreve.

O entrevistador perguntava a Moravia: “- O senhor, porém, não há de negar a Manzoni um sentido da história profundo e incomum.”

E esta era a resposta:

- O que não nego é sobretudo o nível europeu, não provinciano de sua inteligência. Ele é romancista da melhor cepa [...] Além disso, está apoiado num sentido social extraordinário [...] dispõe da capacidade, muito rara na ficção italiana, de descrever quase visivelmente o conjunto de uma sociedade [...] O que arruína Os Noivos é a Providência [...] O catolicismo é o contrário do romance, que se baseia na autonomia das personagens. Mas se é a Providência quem decide por todos... ${ }^{1}$

Com essas reticências se encerrava o comentário sobre Manzoni, que resume o juízo de muitos críticos. Pode-se dizer que desde os primeiros leitores do romance, até grandes nomes, como Croce, não têm faltado vozes que insistem na limitação artística que representaria a visão católica e providencial do romancista. Tais intrepretações têm repercutido mesmo fora da Itália. Sirvam de exemplo entre nós as palavras de Otto Maria Carpeaux. Também ele faz elogios à obra que chama de "o maior romance histórico que jamais se escreveu”. Acrescenta, entretanto, o seguinte: "Manzoni, católico de fé firme, acreditava na Providência divina: por isso não se duvida nunca do desfecho feliz da tragédia". ${ }^{2}$

Tal juízo pode levar à avaliação redutora de um extraordinário escritor. É certo que Manzoni era homem de fé e que a Providência é muitas vezes lembrada em I promessi sposi. Mas não é menos certo que foi complexa sua relação com o catolicismo e que o trágico esteve presente não só em sua arte, mas em sua vida.

Nascido em Milão, em 1785, Alessandro Manzoni viu-se desde cedo privado do convívio dos pais. Internado em colégio religioso, a frieza da disciplina 
e a leitura dos racionalistas ilustrados levaram-no a se afastar da religião. Logo que pôde dispor de seus bens, com cerca de vinte anos, mudou-se para a França napoleônica. Em Paris, a memória do avô materno, um dos grandes iluministas italianos, Cesare Beccaria, abriu-lhe os salões que reuniam os herdeiros da Ilustração racionalista. Os amigos parisienses o confirmaram no liberalismo democrático que sempre o distinguiria. Ainda em Paris, ele conheceu a companheira de sua vida, Henriette Blondel, jovem protestante suíça, com quem se casou pelo rito calvinista. Paradoxalmente, foi Henriette quem levou o marido a se reconciliar com a fé que havia deixado. Mas essa reconciliação, a chamada conversão de Manzoni, desde o início levantou dúvidas nos ambientes religiosos.

Via-se como suspeito que Manzoni continuasse a professar o liberalismo de origem revolucionária, numa época em que quase toda a hierarquia católica sustentava o absolutismo e a união de trono e altar. Além disso, era notório que Manzoni se pusera sob a orientação de clérigos dissidentes, de tendências jansenistas (próximos, portanto, da teologia calvinista e hostis à jurisdição romana). Mais tarde, o escritor se tornaria amigo de um dos grandes filósofos italianos do século XIX, o também sacerdote Antonio Rosmini, cuja obra teológica viria a ser condenada pelas autoridades da Igreja. Enfim, em 1870, quando as tropas italianas entram na cidade de Roma, pondo termo ao governo papal, o velho Manzoni (que morreria três anos depois) não hesita em apoiar a ocupação. Mais ainda: como senador do Reino da Itália, aceita colaborar com os novos governantes.

Percebe-se, portanto, que o catolicismo de Manzoni nada teve de conformista. E é equivocado afirmar que em seu romance uma Providência determinista assegura a solução de quaisquer tragédias. Seria estranho que assim fosse, principalmente em vista do momento em que o escreve. É nos anos ao redor de 1830 que Manzoni preparava a versão definitiva de I promessi sposi - obra publicada em 1827, e, afinal, em 1840. Então, no plano político, seus ideais de liberdade pareciam cancelados pela Santa Aliança. $\mathrm{O}$ escritor assistia à derrocada das insurreições dos liberais italianos, que havia celebrado na ode "Marzo 1821".

Mais duros foram os golpes pessoais que então sofreu. Sua vida transformou-se numa sucessão de lutos: aos poucos ele veria morrer quase todos os filhos. Mas o que o deixou mais consternado foi a morte da mulher, que, para sua maior aflição, ocorreu no dia de Natal de 1833. Manzoni sentiu sua perda quase como sinal da indiferença divina diante da dor humana. O primeiro verso da poesia que deixou dedicada à memória de Henriette, "Il Natale del 1833", dirige a Deus estas palavras amargas: "Si, che tu sei terribile". Toda essa poesia, que Manzoni não teve forças para concluir, é dominada pela imagem desse Deus inflexível ante as súplicas de quem sofre. Eis por que se dizia que as imagens redutoras não se coadunam com o que o sabemos do homem e do escritor. Seria estranho que, enquanto o poeta clamava ante o Deus "terrível", o romancista festejasse um deus ex machina.

Fica bem longe disso a evocação do divino em I promessi sposi. Não seria difícil recordar figuras do romance cuja vida termina em tragédia inexplicável. 
Não me detenho na jovem Gertrudes que, oprimida pelo pai e obrigada a se fazer religiosa, chega ao fim de seus dias a se atormentar num convento. ${ }^{3} \mathrm{Nem}$ me detenho em Cecília, a menina morta. Lembro somente a figura de Tônio, o camponês, que encontramos no início do romance, rodeado de numerosa família. Tônio acaba seus dias sozinho e enlouquecido, na aldeia dizimada pela peste. Só lhe resta repetir o refrão desvairado: "A quem ela [a peste] vem, vem" [ " $A$ chi la tocca, la tocca"; XXXIII, 45-46; LF, 448]. Essa imagem de louco desamparado e a sonoridade de sua frase, no original italiano, bem podem ter ocorrido ao criador de outro louco, que temina solitário pelas ruas de Barbacena, sempre a proclamar: "Ao vencedor as batatas!".

Mas se é enganoso considerar I promessi sposi um romance em que é previsível o desfecho feliz de quaisquer tragédias, certo é que suas páginas estão longe do moralismo sombrio de certas narrativas edificantes. A grandeza literária de I promessi sposi é ponto pacífico até mesmo para os críticos que deploram o catolicismo de Manzoni. Acabamos de ver que Moravia lhe reconhecia qualidades incomuns no panorama da ficção. Hoje se reconhece que, anticipando-se a Stendhal e Balzac, é Manzoni "el primer gran renovador de la tradición narrativa del XVIII" ${ }^{4} \mathrm{E}$ dentre as qualidades que o distinguem, há uma que vem sendo notada, ainda que menos do que merece. Refiro-me a seu fino sentido de humor. Basta lembrar que Pirandello, no ensaio L'umorismo, exalta a figura de don Abbondio (o medroso vigário da aldeia dos noivos). Como Pirandello, outros críticos têm comentado o humorismo desta ou daquela página de I promessi sposi.

Essas observações certeiras, embora restritas, oferecem um bom ponto de partida para nossas reflexões. O romance de Manzoni é obra de um humorista. Isto é o que, a meu ver, certas interpretações não levam em conta. Quem ler I promessi sposi como obra sempre sisuda, como discurso em que o autor expõe a sério suas próprias opiniões, correrá o risco de cair em graves mal-entendidos. Um deles ocorreu logo após a primeira publicação do romance, em 1827.

O caso teve como protagonista o tradutor inglês, Charles Swan. Lendo o original, o tradutor chegou ao ponto em que se alude a Shakespeare. É o trecho em que se diz que o poeta seria "um bárbaro que não era destituído de gênio" ["un barbaro non privo d’ingegno"; VII, 79; LF 97]. Horrorizado, o inglês correu a escrever carta a Manzoni e só prosseguiu a tradução quando este o sossegou, confessando-se admirador de Shakespeare (em cuja obra, aliás, se havia inspirado ao promover a renovação romântica do teatro, com as tragédias Il conte di Carmagnola e Adelchi).

Não me estendo no incidente, que outros já analisaram. Para Giovanni Getto as palavras que espantaram Charles Swan ecoam a obra de um escritor muito lido pelo jovem Manzoni: Voltaire. Este, em 1778, na Lettre à l'Académie Française, emitia a seguinte opinião: "Shakespeare est un sauvage avec des étincelles de génie". ${ }^{5}$ Parece-me, aliás, que terá sido fonte de Manzoni também o capítulo 25 do Candide, que se refere a outro poeta inglês, Milton, chamando-o, igualmente, de "ce barbare". Tais apreciações, como se sabe, eram ditadas pelo 
classicismo voltaireano. Daí o efeito humorístico que adquiriam, ao ser reproduzidas na obra de Manzoni, um dos próceres do romantismo italiano.

Vejo nesse caso o exemplo de como se pode equivocar quem se esqueça do humorismo de I promessi sposi. Mais ainda: estou convencido de que o humorismo do romance não se restringe a esta ou daquela página ou personagem. Vai muito além: é algo que nasce da própria organização da obra. Na estrutura de $I$ promessi sposi, temos uma planejada diferença de perspectivas. Estas se originam de um recurso literário de conseqüências ainda pouco medidas. Refiro-me ao ponto de partida da narração.

É bem sabido que tudo neste romance começa com a pretensa descoberta de um manuscrito barroco. Manzoni alega que lhe chegou às mãos um texto de escritor anônimo do século XVII, onde se lia uma velha história ocorrida no território de Milão. Sabe-se que o subtítulo de I promessi sposi é este: "História milanesa do século XVII, descoberta e refundida por Alessandro Manzoni" ["storia milanese del secolo XVII scoperta e rifatta da Alessandro Manzoni"]. O romancista deixa claro que não quer ser visto como autor da história: simplesmente a teria descoberto e reescrito ou refeito. Desde o início diz que o autor seria outro, seria o anônimo escritor barroco, indicado como secentista. Essa idéia é de tal importância que perpassa o romance até o final. As últimas linhas da obra insistem em distinguir "quem a escreveu" ["chi l'ha scritta"] e "quem a consertou" ["chi l'ha raccomodata"; XXXVIII, 69; LF, 523].

Não é preciso lembrar que o recurso a semelhantes achados foi inaugurado no romance moderno por Cervantes, um dos grandes mestres de Manzoni. É bem sabido que a história do Quixote constaria do texto árabe de Sidi Hamete Benengeli. A pluralidade de perspectivas da obra-prima cervantina funda-se, entre muitos outros elementos, neste: as aventuras de um herói cristão são narradas por um muçulmano em um manuscrito que, traduzido, volta a circular entre cristãos.

A exemplo de Cervantes, Manzoni parte, também, do suposto manuscrito alheio. Mas com uma diferença. Em Cervantes, as perspectivas abertas pelo texto árabe decorreriam da diferença entre duas tradições culturais, ao passo que em Manzoni as perspectivas abertas pelo manuscrito barroco decorrem da distância que a passagem do tempo faz surgir dentro da mesma cultura. "Mudam-se os tempos, mudam-se as vontades", digamos com Camões: o manuscrito de I promessi sposi não seria contemporâneo do reelaborador (como o de Sidi Hamete), mas teria sido escrito séculos antes. Nisso se funda o jogo de perspectivas do romance de Manzoni.

De fato, o manuscrito fictício ocupa lugar cuja importância não me parece ter sido suficientemente avaliada. Embora não faltem estudos dedicados à figura do anônimo secentista, ${ }^{6}$ continua-se a esquecer o alcance de seu papel na construção do romance e na formulação de alguns temas centrais, entre os quais o religioso. 


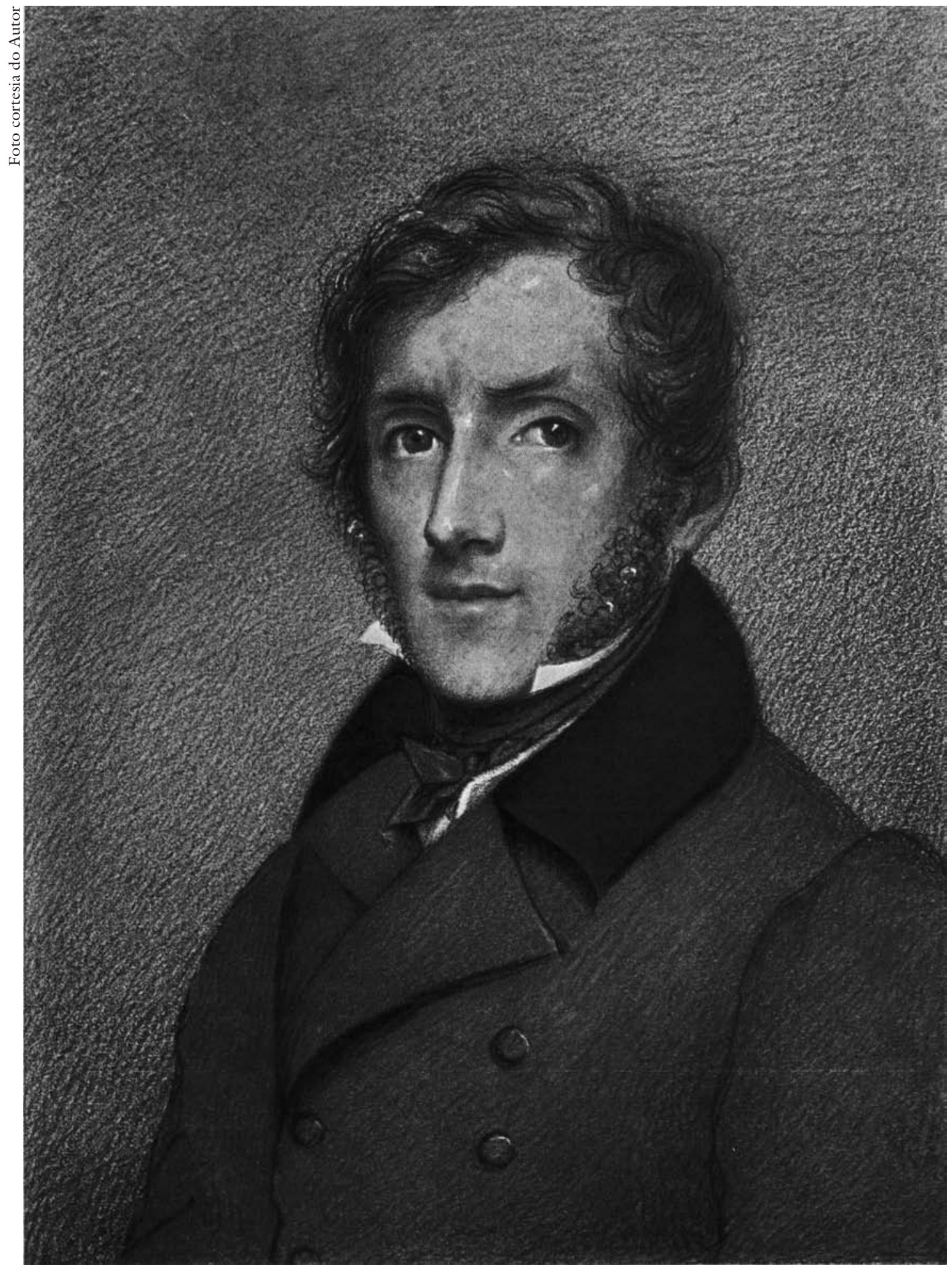

Retrato de Alessandro Manzoni em 1810, por C. Gerosa. 
Prova de esquecimento é que muitos tradutores de Manzoni passam por alto o subtítulo do romance, que fala em história "descoberta e reescrita" (ou "refundida", como prefere a tradução LF). Além disso, o que é mais grave, muitas traduções omitem as páginas iniciais do romance, as que reproduzem o texto do secentista. Outras as traduzem, mas sem conservar o estilo de época (é o caso da tradução aqui reproduzida). Ora, isso é nada menos que desastroso, pois, como se acaba de ver, a referência implícita ao texto descoberto é dado permanente em I promessi sposi. Toda a trama se abre com o magistral pastiche de manuscrito barroco, em que se respeitam grafia e retórica da época. Só depois de lhe transcrever alguns parágrafos, o pretenso descobridor reconhece ser impossível apresentar a leitores de seu tempo o texto escrito duzentos anos antes. Daí a decisão de recontar em linguagem moderna uma história escrita em estilo antiquado. A reelaboração consistiria em trabalho semelhante ao do tradutor ou adaptador, consistiria em "refazer-lhe a linguagem" ["rifarne la dicitura"; Intr., 11; LF, 7].

Graças ao pretenso achado, portanto, assistimos à criação de duas personagens fundamentais: $\mathrm{o}$ autor anônimo e o reelaborador ou recontador da história. Este último é alter ego de Manzoni, mas também fictício. Sim, pois sabemos que nenhuma das biografias do escritor registra o achado de um manuscrito barroco... A descoberta vale somente no plano da ficção.

Chega a ser surpreendente que a crítica atual, especialmente a de matriz bakhtiniana, pouco ou nenhum peso continue a dar à polifonia desse romance, que se diz escrito a quatro mãos, separadas por dois séculos. Continua-se a ver em I promessi sposi somente a voz do católico Manzoni, a celebrar a Providência em narração sisuda, nos moldes da obra de Walter Scott. A esse respeito, aliás, há quem chegue a pensar que em I promessi sposi teríamos mero exemplo, embora notável, da moda inaugurada pelo romancista escocês. Ora, sem dúvida Manzoni foi leitor de Scott, mas os efeitos dessa leitura vêm sendo superestimados pela crítica. Quem o diz é alguém insuspeito: um estudioso e tradutor de Manzoni para o inglês, Archibald Colquhoun. Para ele, "[Scott's] influence has been overemphasized by literary historians".

Tende-se a subestimar em Manzoni a leitura de romances barrocos e ilustrados. Não que não se tenha notado a importância da cultura barroca em $I$ promessi sposi. Basta lembrar que Luigi Russo chega a dizer que o verdadeiro protagonista da obra é o século XVII. Mas o que pouco se explora é o diálogo de I promessi sposi com os escritores daquele século e do seguinte. Ora, foi lendo os romances barrocos que Manzoni preparou o seu. Ele próprio, em carta de agosto de 1822, ao amigo Cattaneo, declara-se entregue à leitura assídua dos escritores do século XVII. ${ }^{8} \mathrm{Nem}$ se esqueça que na juventude as leituras de Manzoni se haviam voltado para o romance francês do século XVIII. O dado é conhecido. Tanto que na já lembrada figura de Gertrudes, forçada a viver no convento, há quem aponte reminiscências de La religiuse, de Diderot.

Por tudo isso, o que me parece é que I promessi sposi trava diálogo privilegiado com os romances ilustrados e barrocos. E no seiscentista anônimo temos 
a chave desse diálogo. Já se disse que o descobridor do manuscrito resolve reelaborar-lhe o linguajar. Trata-se, pois, de reelaboração do estilo e não das idéias do texto. Estas seriam as do anônimo barroco. Isso, em princípio, nos poria diante do ideário da Itália do século XVII, de uma Itália saída do Concílio do Trento e sujeita ao domínio espanhol. O que se busca é modernizar a linguagem de um romance pautado por esse ideário. E aqui é que começa a citada discrepância de perspectivas.

De fato, é o secentista, ao introduzir os temas do romance, quem proclama seus ideais religiosos, inspirados pela reforma tridentina. Com estilo pomposo, ele é quem anuncia que fará ver o contraste entre um "nobilíssimo Céu" ["nobilissimo Cielo"] e um "inferno de atos tenebrosos" ["inferno d'atti tenebrosi"] Seu relato desde o início proclama a luta entre as "bondades angélicas" ["buontà angeliche"] e as "operações diabólicas" ["operationi diaboliche"]. Embora se disponha a narrar aventuras de "gente miúda e de pouca importância" ["genti meccaniche e di piccol affare"], o anônimo as situa dentro do grande panorama político da monarquia católica e espanhola, pois tudo se passa em terras postas sob o "amparo de El-Rei Católico, Nosso Senhor" ["l'amparo del Re Cattolico, nostro Signore"; Intr., 3-5; LF 3].

É o anônimo, como se percebe, quem nos convida a ver a ação divina em termos que se aproximam da interpretação católica e providencial. Nem outro discurso seria verossímil. Pois estamos diante de personagem de ficção que se supõe a escrever no século XVII, século por excelência providencialista. É o século que verá aparecer os Sermons sur la Providence e o Discours sur l'histoire universelle, de Bossuet; é o século em que o pincel de Pietro da Cortona criará o Trionfo della Divina Provvidenza, na Roma de Urbano VIII; é o século em que os libertinos, opondo à Providência os males do mundo, reabrirão a vexata quaestio vinda do estoicismo grego e do De Providentia, de Sêneca. O debate, aliás, seria herdado pelo século XVIII, com Vico e Voltaire, para chegar até o pensamento de De Maistre.

Perfeita, portanto, a figura literária criada por Manzoni, o anônimo barroco, e muito coerente sua concepção religiosa da história, em que ressoa o pensamento católico do século XVII. Parece-me, aliás, notável nesse discurso do anônimo a identificação entre o campo da política e o campo da religião cristã, na linha do De civitate Dei agostiniano, o que dá ao manuscrito outra nota característica do pensamento católico da época: a de polêmica antimaquiavélica.

É preciso frisar, contudo, que a divergência de perspectivas de I promessi sposi não fica restrita às oposições entre a visão barroca e a expressão romântica. A diferença é ainda mais complexa e envolve a fonte donde teriam derivado as informações que fundamentaram o manuscrito.

É de novo o anônimo quem se refere a esta fonte, ao declarar que teve "notícia de fatos memoráveis" ["hauendo haunto notitia di fatti memorabili"; Intr., 3; LF, 3]. Contudo, quem aventa a hipótese de como lhe teriam chegado 
tais notícias é, dessa vez, o recontador, com quebra do propósito de se limitar a reelaborar o texto. Diz ele que a fonte do secentista seria a versão oral do protagonista do romance, o camponês Renzo, pois "tudo leva a crer que o nosso anônimo a tivesse ouvido dele mais de uma vez" ["tutto conduce a credere che il nostro anonimo l'avesse sentita da lui più d' una volta"; XXXVII, 11; LF, 501].

Vemo-nos, assim, diante de obra semelhante a um palimpsesto: o que leríamos seria o aggiornamento romântico da linguagem de um texto escrito pelos padrões barrocos, texto cujo substrato seria a narração verbal de um camponês. Diante disso, há que levar em conta em que medida as convicções desse camponês se refletem nas idéias do romance e, entre elas, nas idéias providenciais, que ele repetidamente proclama.

Repetidamente, pois é Renzo o maior arauto da Providência ao longo do relato. Ele é quem enxerga a ação providencial sempre que acontecimentos favoráveis o livram de dificuldades. Suas interpretações despontam quando chega faminto a Milão e encontra um pãozinho caído na rua. "No pão pensou a Providência", "Aqui está o pão da Providência", diz ele preparando-se para abocanhálo ["Ci ha pensato la Provvidenza", "ecco il pane della Provvidenza"; XIV, 25; LF 193]. Páginas depois nós o vemos saído da embriaguez, durante a qual falou como exaltado, o que o levou a ser tomado por um dos arruaceiros que instigavam a população contra as autoridades. Apesar disso, consegue escapar da perseguição dos beleguins e pôr-se em fuga para Bérgamo, onde mora seu primo. Confiante, não deixa de agradecer aos céus: "A Providência Divina, que me ajudou até agora, há de me ajudar também para o futuro" ["La Provvidenza m’ha aintato finora, non mi abbandonerà per l'avvenire"; XVII, 40; LF, 236]. "Existe a Providência Divina!" ["La c'è, la c'è la Provvidenza!"; XVII, 42], diz logo depois, quando descobre que ainda lhe sobraram no bolso uns tostões para socorrer mendigos. "Quando eu digo que há uma Providência!" ["L’ho detto io della Provvidenza!"; XVII, 251; LF, 238], exclama, quando chega a Bérgamo e encontra o primo de braços abertos. Acrescente-se que a narração nos dá conta não só dos passos do camponês, mas de "todos os [seus] pensamentos" ["tutti i suoi pensieri"; XVII, 43; LF, 237]. Assim sabemos que ele se prepara para dormir numa cama improvisada "que a Providência lhe preparara" ["la Provvidenza gli aveva preparato"; XVII, 21; LF, 232]. Sabemos ainda que, refletindo sobre os tostões que achara no bolso, entende que foi para ajudar os pobres que "a Providência havia mantido em reserva justamente os últimos ceitis de um estrangeiro" ["la Provvidenza aveva tenuti in serbo proprio i quattrini d'un estraneo"; XVII, 43; LF, 237].

Observo aqui algo que tem passado em silêncio. É que, exceto a alusão feita ao encontrar o pãozinho, todas as demais ocorrem no capítulo XVII do romance, às vezes com grande proximidade umas das outras. A freqüência é tal que esse capítulo XVII se poderia mesmo chamar de "capítulo da Providência". Tenho para mim que essas alusões nos remetem uma vez mais ao Candide. E o que é mais curioso, também aqui ao capítulo 17. Nele acharemos esta afirmação do protagonista: "Allons, dit Candide, raccomandons-nous à la Providence". 


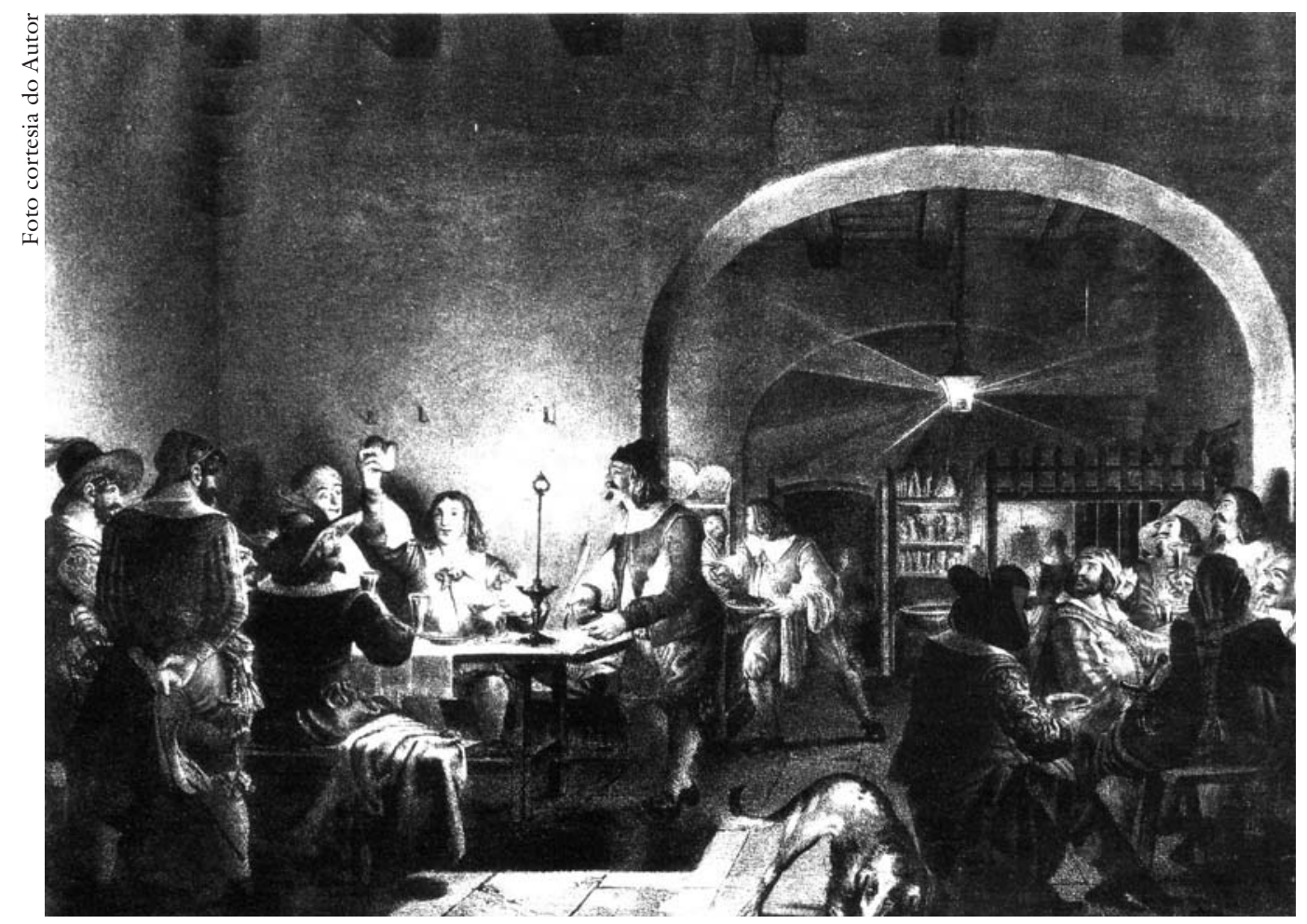

Renzo exibe o "pão da Providência”. Gravura de G. Gallina (1829).

O que parece unir o atribulado Candide ao atribulado Renzo é justamente a visão um tanto utilitária da Providência. Estaríamos diante de uma concepção que parece entrever uma "Providência pronto-socorro". Tem-se a impressão de que Renzo tende a ser o porta-voz do ingênuo providencialismo escarnecido pelos libertinos e não muito diferente do atribuído por Moravia ao próprio Manzoni.

Ora, um camponês, como Renzo, embora fosse cristão desde o berço, estava longe de ter sólida instrução teológica. Sabemos que sua prática religiosa estava mesclada a crendices de infância. O romance aponta seu medo de aparições de almas do outro mundo e as orações que faz para aplacá-las ou espantálas: "como na sua mente começassem a suscitar certas imagens, certas aparições nela deixadas em reserva pelas novelas ouvidas contar em criança, então, para enxotá-las ou para acalmá-las, recitava, caminhando, orações pelos defuntos” ["nella sua mente cominciavano a suscitarsi certe immagini, certe apparizioni, lasciatevi in serbo dalle novelle sentite raccontar da bambino; cosi, per discacciarle, o per acquietarle, recitava camminando, dell'orazioni per i morti"; XVII, 13; LF, 230].

Não me parece que a crítica tenha atribuído importância a essa informação. Creio, entretanto, que é fundamental, ainda mais por ocorrer justamente no capítulo XVII, no "capítulo da Providência”. Em doutrina religiosa, como em outros assuntos, Renzo era um camponês de seu tempo. Sabemos que suas idéias não eram melhores que as costumeiras na época, pois ele não era "abso- 
lutamente um homem superior ao seu século" ["non essendo punto un nomo superiore al suo secolo"; XI, 70; LF, 163]. Ora, seu século, como já vimos, assiste a um providencialismo de origem religiosa, sim, mas secularizado e espalhado pela sociedade em geral. E o romance de Manzoni não deixa de registrar as origens e a difusão desse providencialismo.

Já nos primeiros capítulos, quem se refere à Providência é um capuchinho, Cristóvão. Ao defender os noivos, Renzo e Luzia, de seu opressor, Don Rodrigo, o religioso é alertado por um velho criado sobre as maquinações do patrão. Atribui, então, à Providência o aviso: "Eis aí um fio, pensava ele, um fio que a Providência me põe nas mãos" [ "Ecco un filo, pensava, un filo che la provvidenza mi mette nelle mani”; VI, 26; LF, 76]. Diga-se de passagem que essa alusão expressa, no capítulo VI, é a única feita no romance antes das citadas exclamações de Renzo.

Como guia espiritual da noiva de Renzo, esse capuchinho seria, portanto, o grande incentivador da visão providencial dos noivos. De ambos, digo, pois a noiva, Luzia, é outra personagem a quem se atribui visão providencial. Ao se ver livre do poder de seu raptor, sabemos que a jovem "se abandonara à Providência" ["s'era abbandonata alla Provvidenza"; XXV, 20; LF, 338; cfr. XXIV, 38-39]. Além disso, é de crer que toda a aldeia dos noivos estivesse, mais ou menos, exposta a semelhante pregação. Tanto que o próprio vigário a certa altura exclama: "Será o que a Providência quiser!" ["Sarà quel che vorrà la Provvidenza!"; XXX, 4; LF, 400].

Mas não só entre o clero e não só nas aldeias se difundia o providencialismo do século XVII. Bem por isso o romance parece atribuí-lo também a letrados, como o autor anônimo. Mas não só a ele. Note-se que a maior autoridade política de Milão, o governador, diante da ameaça de peste, manda que, tomadas as precauções possíveis, "esperassem na Providência" ["si sperasse nella Provvidenza”; XXVIII, 70; LF, 384].

Essa difundida vulgata do providencialismo, ainda que escapasse a formulações supersticiosas, mal evitaria ambigüidades. No romance encontraremos, por exemplo, a expressão "provvidenza" empregada em sentido amplo, como simples alusão a um evento favorável, não necessariamente associado à ação divina. Tal acepção vaga e coloquial ainda hoje se faz presente na língua italiana, na qual a palavra "provvidenza" pode passar por equivalente de boa sorte. Nesse sentido é que a emprega o menino Menico, ao encontrar os noivos a tempo de os avisar da tentativa de rapto de Luzia. Diz ele: "Que sorte que os achei aqui todos!" ["provvidenza che vi trovo qui tutti!"; VIII, 55; LF, 108]. É assim que a usa o próprio Renzo, ao chegar a Milão e ao decidir tentar a sorte na primeira hospedaria que encontrar: "Seja como Deus quiser!" ["Alla provvidenza!"; XIV, 19; LF, 191]. É assim também que a lemos no importante capítulo XVII, ao se comentar que Renzo teve sorte em contar com o primo Bártolo, pois já não dispunha dos haveres que deixara na aldeia. Diz o romance: "De fato, tudo andou bem e tão de acordo com as promessas de Bártolo que julgamos inútil 
fazer disso um relato particular. E realmente foi verdadeiramente providencial, porquanto os bens e o dinheiro que Renzo tinha deixado em casa, dentro em pouco veremos o quanto ele podia contar com eles" ["Tutto infatti andò bene, e tanto a seconda delle promesse di Bortolo, che crediamo inutile di farne particolar relazione. E fu veramente provvidenza; perché la roba e i quattrini che Renzo aveva lasciati in casa, vedremo or ora quanto fosse da farci assegnamento"; XVII, 60; LF, 240].

A ambigüidade do termo às vezes é tal que "provvidenza" chega a ser tomada em sentido decididamente profano, contrário à visão cristã. Haja vista o comentário de um mercador milanês, indignado com os saques às lojas da cidade. Diz ele que todos os arruaceiros hão de ser sumariamente enforcados. E acrescenta que o enforcamento é necessário para evitar que a gente se acostumasse a levar mercadorias sem pagar. A forca, nesse caso, seria obra providencial. Ou em suas palavras: "É providencial, creiam, era uma coisa necessária" [ "È una provvidenza, vedete, era una cosa necessaria"; XVI, 53; LF, 225].

Tudo isso tem de ser lembrado ao se tratar das conviç̧ões providenciais de Renzo, impregnadas, por um lado, das crendices da infância e, por outro, das ambigüidades correntes nas idéias de seu século. Pois bem: essa concepção popular do camponês contrapõe-se no romance à concepção erudita do secentista. Cria-se, assim, o contraponto humorístico de visões. A palavra "Provvidenza" não parece significar exatamente o mesmo para quem conta a história e para quem a escreve.

Nem se limita a isso a diferença de perspectivas que vimos apontando. $\mathrm{O}$ possível desentendimento sobre a palavra Providência é sintoma de barreiras ainda mais graves de comunicação. Em primeiro lugar, porque os noivos, Renzo e Luzia, mal sabem expressar-se, ou, como observa o vigário, falam "com simplicidade" ["alla carlona"; XXXVIII, 39; LF, 517], isto é, sem domínio gramatical da língua italiana. Como se não bastasse, ambos são analfabetos. E isso é o que os porá em risco permanente de falência de comunicação.

O analfabetismo dos noivos é ponto fundamental, que costuma passar quase despercebido. Um dos poucos que o notaram foi Italo Calvino, ${ }^{9}$ que diz o seguinte: "Renzo e Luzia não sabem ler nem escrever: em Os Noivos este fato tem relevância decisiva, à qua não creio se tenha dado a devida importância" ["Renzo e Lucia non sanno leggere né scrivere: nei Promessi Sposi questo fatto ba un rilievo decisivo, cui non mi pare sia stata data la importanza dovuta"]. Para não nos alongarmos, basta aludir a um exemplo, que nos faz pensar em uma bela cena de Central do Brasil, de Walter Salles. A certa altura, vendo-se distante da família da noiva, Renzo precisa recorrer aos serviços de um escrivão de cartas. É então que o romance se estende sobre os apuros do analfabeto que depende do letrado para se expressar. A carta que daí nasce é parto malogrado, pela imprecisão de quem fala e pela vaidade de quem escreve impondo seu próprio estilo e suas próprias próprias idéias. Essa é uma página antológica do romance, que, por ser longa, é impossível citar [cfr. XXVII, 17-21]. É ainda Calvino ${ }^{10}$ quem 
observa: "Um parágrafo que sem hesitar eu poria entre os mais belos do livro é o que Manzoni dedica às cartas com que os analfabetos se comunicam" [" $A$ come gli analfabeti comunichino per lettera, Manzoni dedica un paragrafo che metterei senz'altro tra $i$ più belli del libro"].

Já antes desse episódio, sabíamos que as as tentativas de comunicação entre Renzo e os letrados costumam acabar em desastres. Lembre-se o capítulo III, em que ele procura um advogado para tentar obter ajuda contra o fidalgo opressor. Renzo tenta explicar-se, mas o advogado o interrompe, dizendo-lhe que se limite a expor o fato - "Diga-me o fato como se passou" ["Ditemi il fatto come sta"; III, 18; LF, 38]. O camponês obedece, e a interpretação do fato, segundo o advogado, é que o camponês não é vítima do crime: é o próprio criminoso.

Ora, o relato feito ao advogado parece análogo ao relato feito ao anônimo. Também aqui o camponês teria narrado os fatos, que o secentista julgou memoráveis: "baunendo aunto notitia di fatti memorabili". Mas, no caso da exposição ao secentista, os fatos narrados pelo camponês sofreram desventuras ainda maiores. Isso porque seu relato ao autor do manuscrito, como já vimos, teria sido feito mais de uma só vez, "più d’ una volta”. Ou seja, somos levados a pensar em variantes, mais ou menos distintas, das versões orais do próprio Renzo.

Diante disso, dizer que o analfabeto Renzo foi quem passou notícias ao escritor barroco, é dizer que se travou um diálogo de surdos. Se um letrado, interpretando os fatos que Renzo lhe contara, conseguiu transformá-lo de vítima em criminoso, não seria de surpreender que, em circunstâncias ainda mais desfavoráveis, outro letrado, o anônimo barroco, o transformasse de cético em devoto da Providência... Só mesmo por milagre poderíamos conhecer o pensamento do camponês em relação à Providência ou a qualquer outro tema. Tudo o que se pode observar é que, em um ponto, ser analfabeto foi "provvidenza" para Renzo: se pudesse ler I promessi sposi, talvez levasse susto maior que o que levou ao consultar o advogado...

Como se não bastasse a confusão inextricável da comunicação entre a fonte oral e o redator erudito, a ironia do recontador vem complicá-la ainda mais. Ironia que, se não poupa a Renzo, também não poupa ao secentista. Exemplo desse último caso se acha na descrição da biblioteca de don Ferrante (cf. XXVII, 42-57, especialmente 55). Os comentários às palavras do anônimo confirmam que o recontador é herdeiro da Ilustração e de sua polêmica antibarroca: relembre-se Candide, com a biblioteca de Pococurante que, aliás, remonta à biblioteca do Quixote. Essa atitude irônica é o que torna ainda mais complexo todo o processo de comunicação.

Creio que estará mais claro, a essa altura, por que que é preciso ler o romance ao menos cum grano salis, que é o que parece ter faltado a leituras como a do primeiro tradutor inglês ou de críticos como Moravia. Atribuir diretamente a Manzoni qualquer afirmação da obra é esquecer-se da construção de $I$ promessi sposi e da conturbada redação do manuscrito fictício, que fundamenta a obra. Note-se de passagem como é curiosa a recepção de alguns clássicos. Já se 
disse que o manuscrito de I promessi sposi cria distância temporal, assim como seu inspirador, o manuscrito de Dom Quixote, cria distância de culturas. Mas o que talvez ainda não se tenha observado é que Cervantes e Manzoni vêm sendo recebidos pela crítica de forma contrastante, embora paralela. É sabido que até o romantismo Dom Quixote foi visto como paródia do romance de cavalaria; depois, passou a ler-se como romance que espelha a condição trágica do ser humano. O romance de Manzoni, ao contrário, sempre tem sido visto como obra séria, de inspiração histórica e religiosa. Caberá talvez à crítica do futuro ressaltar em I promessi sposi uma dimensão esquecida: a de obra-prima do humorismo, tendente à paródia do romance barroco.

Há, contudo, nas últimas páginas, um momento em que o humorismo dá lugar à gravidade de uma reflexão final. Seja essa reflexão também o fecho de nossas considerações.

No último capítulo, passadas as peripécias do turbulento noivado, Renzo faz um balanço e conclui que os dissabores lhe serviram de lição. "Aprendi” [ " $\mathrm{Ho}$ imparato"; XXXVIII, 66; LF, 522]: assim começam as palavras com que descreve as lições que recebeu da vida. E o que aprendeu foi a frear a língua, a beber com moderação, a ficar longe de arruaças. Em suma, Renzo julga que as desventuras lhe ensinaram a evitar a repetição das falhas que as teriam causado. A Providência o teria feito passar por contratempos a fim de o tornar mais esperto no futuro. Teríamos aqui algo como uma versão popular do Bildungsroman ilustrado.

Quem não se conforma com essa conclusão é Luzia. Ela, que não se envolveu em arruaças, não falou demais e muito menos bebeu, não entende bem que falhas a teriam feito merecer perseguições, seqüestros, peste e outras agruras.

É então que ambos se põem a pensar juntos e concluem que os males nem sempre decorrem de culpas pessoais. Os males são inevitáveis. Mas em qualquer caso a confiança em Deus os suaviza e os torna úteis para uma vida melhor. Suas palavras são estas: “os dissabores vêm, realmente, muitas vezes por se lhes haver dado ocasião, mas a conduta mais cauta e mais inocente não basta para os conservar distantes; e que quando eles vêm, ou com ou sem culpa, a confiança em Deus os abranda e os torna úteis para uma vida melhor" [“ $i$ guai vengono bensí spesso perché ci si è dato cagione, ma che la condotta piú cauta e piú innocente non basta a tenerli lontani, e che quando vengono, o per colpa o senza colpa, la fiducia in Dio li raddolcisce e li rende utili per una vita migliore"; XXXVIII, 68; LF, 523]. Essa reflexão do casal é aprovada e pelo recontador, que a transforma em conclusão do romance todo. Diz ele: "Esta conclusão, se bem que tirada por gente humilde, afigurou-se-nos tão justa que decidimos pô-la aqui, como o sumo de toda a nossa história" ["Questa conclusione, benché trovata da povera gente, c'è parsa cosi giusta che abbiam pensato di metterla qui, come sugo di tutta la storia"; ibidem]. Essa aprovação é que dá ao final do romance a marca de seriedade, a que há pouco aludi. E a seriedade desta nota não deixa de ser surpreendente.

Surpreende, em primeiro lugar, que essa conclusão confesse ser diferente da que havia escrito o anônimo. O recontador deixa claro que foi ele próprio 
quem interveio nesse ponto. Foi ele quem introduziu nesse lugar a reflexão, para transformá-la em fecho e em síntese do romance ("abbiam pensato di metterla qui, come sugo di tutta la storia", diz ele). Fica, assim, claro que sua intervenção vai muito além da reelaboração lingüística e substitui o próprio desenlace original, que só podemos tentar reconstituir graças à lembrada relação paródica estabelecida com o texto anônimo.

Redigido segundo as regras retóricas da época, o manuscrito teria de retomar os grandes temas anunciados no início. Ou seja, o secentista teria de concluir reinserindo os "fatti memorabili" no panorama do sobre-humano combate, em que as potências celestiais se empenhariam por assegurar o triunfo terreno das forças do bem, representadas pelo governo "del re Cattolico, nostro signore". Mas esse fecho do letrado é o que o recontador exclui, substituindo-o pela conclusão dos camponeses, que lhe parece acertada, embora provinda de gente humilde, "benché trovata da povera gente".

Alguns veriam nessa cláusula certa atitude de superioridade às vezes atribuída ao escritor diante de personagens populares. A meu ver, entretanto, o que sobressai é a afirmação de que personagens populares e analfabetos, afinal, souberam refletir melhor que o erudito letrado, autor do manuscrito. O recontador não quer encerrar com as considerações finais do letrado secentista. Por isso é que nos quer fazer vislumbrar aqui a expressão fiel do pensamento da "povera gente", um ponto intacto do palimpsesto, o milagre de entendimento a que aludimos, o improvável oásis de comunicação perfeita entre letrados e iletrados.

Mas se o recontador não dá ao secentista a palavra final, é certo que exclui também a síntese apressada de Renzo que, como vimos, interpretava seus contratempos como série de lições miúdas. A obra de Manzoni não se encerra com a visão grandiosa do De civitate Dei, mas tampouco se encerra com a imagem ingênua do "Deus-pronto-socorro".

Pelo contrário, pois justamente nessa conclusão do romance desaparece a palavra tantas vezes citada pelo protagonista: "Provvidenza". É como se o recontador se afastasse das ambigüidades suscitadas pelo desgaste do termo. Até aqui a proteção do céu parecia clara, manifestava-se a Renzo por meio de sinais evidentes: o pão achado na rua, o dinheiro que sobrou no bolso, o primo de braços abertos. Indícios que permitiriam testemunhar o infalível socorro divino. Os contratempos pareciam compreensíveis, seriam fases de aprendizado árduo, sim, mas pontuado de evidências portadoras de sentido. Os males, no fundo, se tornariam lógicos e até pedagógicos, seriam as linhas tortas da Providência, pelas quais Deus escreve certo a lição-de-casa que vai ensinando: "Ho imparato...".

Nada disso se encontra na reflexão escolhida para fecho do romance. Os males podem ocorrer com ou sem culpa de quem os sofre. A ação divina que os permite deixa de ser compreensível em termos de pedagogia humana. Não há nos males nenhuma lógica, nem deles podemos tirar qualquer ensinamento óbvio. Não há no sofrimento evidências portadoras de sentido. Sofrem culpados e inocentes. O mal é sempre absurdo. 

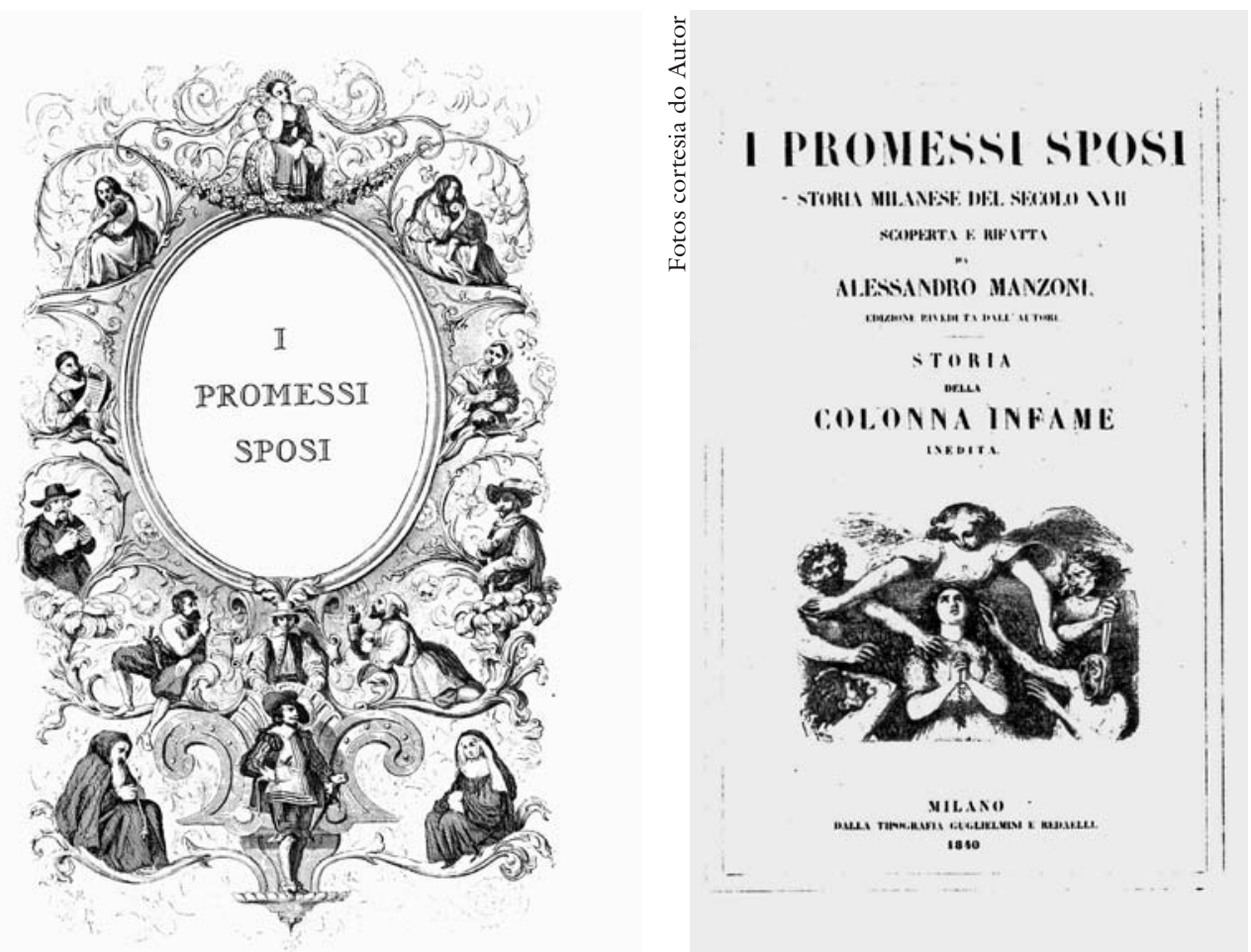

Ilustração e Folba de rosto da edição definitiva de I Promessi Sposi (1840).

A conclusão, portanto, leva-nos a olhar para além da história de Renzo e Luzia e a reevocar o desespero da monja forçada, a morte da criança, a loucura solitária do aldeão e tantas outras figuras cuja história termina em dor inexplicável. Diante do sofrimento que vem "con colpa e senza colpa” só resta confiar cegamente, só resta a "fiducia in Dio". É com uma inesperada imagem que a narração se fecha. Estamos diante de um Deus cujas razões não se enxergam.

Essa conclusão expressa toda a inquietação religiosa do escritor e de seus tempos. É a mesma inquietação poucos anos depois proclamada por Kirkegaard, quando nas páginas de Temor e tremor apontaria em Abraão, pronto a sacrificar o filho, o modelo de confiança cega num Deus de exigências incompreensíveis. Essa é a imagem do divino que conclui I promessi sposi. Mas essa é também a imagem do divino que Manzoni vislumbrava ao escrever a versão final de seu romance. É a imagem que descobria ao se separar de Henriette. É a imagem do "Natale del 1833" e do Deus "terribile".

Notas

1 Alberto Moravia. Entrevista sobre o Escritor Incômodo. São Paulo: Civilização Brasileira, 1986. p.93.

2 Otto Maria Carpeaux. História da Literatura Ocidental. Rio de Janeiro. O Cruzeiro, 1962. v. IV, p.1799.

3 "depois de muito se enfurecer e debater, se havia arrependido e acusado [...] sua vida atual era um suplício voluntário tal que ninguém, salvo se a matasse, poderia achar 
outro mais severo" [“...dopo molto infuriarsi e dibattersi, s'era ravveduta, s'era accusata [...] la sua vita attuale era supplizio volontario tale che nessuno, a meno di non togliergliela, ne avrebbe potuto trovare uno più severo; XXXVII, 45; LF, 507]. As citações de I promessi sposi seguem a edição de Fausto Ghisalberti (Milano: Hoepli, 1964); o algarismo romano indica o capítulo; o arábico, o respectivo parágrafo. A tradução reproduzida é a de Luís Leal Ferreira, Os noivos (Petrópolis: Vozes, 1951), aqui citada como LF, com indicação de página. Não me parece sustentável a interpretação dos críticos que vêem na conversão de Gertrudes um exemplo da "provvida sventura" do Adelchi. As palavras que descrevem o final da monja parecem-me aludir à conformidade da sentenciada, mais que à conversão da arrependida.

4 María Nieves Muñiz. “Alejandro Manzoni: entre el silencio y el escándalo”. Trata-se da introdução da autora, catedrática de Filologia Italiana da Universidade de Barcelona, à sua tradução do romance de Manzoni, Los novios (Madrid: Cátedra, 2005, 3aㅗ , p.19).

5 Manzoni e Shakespeare. Lettere Italiane, v.2, p.187-236, 1967.

6 Cf., por exemplo, Hans Grosser. Osservazioni sulla tecnica narrativa e sullo stile nei Promessi Sposi. Giornale Storico della Letteratura Italiana, v.CLVIII, p.409-40, 1981.

7 Archibald Colquhoun. Preface. In: The Betrothed. London: Everyman's Library, 1968. p.x.

8 Cf. Manzoni, Lettere, a.c. di C. Arieti. Milano: Mondadori, 1970. p.283.

9 Italo Calvino. I Promessi Sposi: il romanzo dei rapporti di forza. In: Una pietra sopra. Milano: Mondadori, 1995. p.322 (tradução minha).

10 Ibidem, p.323. Lembrem-se também as falhas de comunicação entre Luzia e a fidalga dona Praxedes, que, confundindo "il cielo" e "il suo cervello", tratava a camponesa com severidade, a fim de reeducar quem lhe parecia uma criatura quase desencaminhada [cf. XXV, 25-31 e XXVII, 31-36].

RESUMO - O ROMANCE de Manzoni costuma ser visto como expressão da fé religiosa do autor na Providência. Mas é preciso ressaltar que Manzoni, mestre da ficção, declina a autoria de I promessi sposi, apresentando-se como adaptador de um anônimo manuscrito barroco, cuja última fonte seria o relato oral de um camponês analfabeto. Tal estrutura, que dá ao romance uma pluralidade de perspectivas e um acentuado sabor humorístico, deve ser levada em conta para evitar interpretações equivocadas de temas como o da Providência.

PALAVRAS-CHAVE: Manzoni, Literatura italiana, Romance ocidental, Humor, Providência. ABSTRACT - MANZONI's novel is often seen as a direct expression of the author's faith in Divine Providence. Yet, it should be underlined that as a master of fiction Manzoni disclaims authorship of I Promessi Sposi, presenting himelf as the editor of an anonymous baroque manuscript, whose ultimate oral source is said to be an illiterate peasant. While giving the novel a plurality of perspectives and a distinct humouristic flavour, that structure should be considered to avoid misleading interpretations of themes such as Divine Providence.

KErWORDS: Manzoni, Italian Literature, Western novel, Humour, Divine Providence.

Pedro Garcez Ghirardié professor titular de Literatura Italiana da Faculdade de Filosofia, Letras e Ciências Humanas da USP. @-pegg@usp.br

Recebido em 7.8.2006 e aceito em 21.8.2006. 